ARCHIWA - KanCELARIE - ZBIORY

NR $4(6) / 2013$

BOHDAN RYSZEWSKI

Uniwersytet Warminsko-Mazurski w Olsztynie

\title{
WSPOMNIENIE O SEMINARIUM DOKTORANCKIM ZAKŁADU ARCHIWISTYKI UNIWERSYTETU Mikolaja KoperniKa W LATACH 1966-1974
}

Słow a kluczowe: Zakład Archiwistyki UMK; kształcenie archiwistów w UMK; seminarium doktoranckie z archiwistyki w UMK; seminarium doktoranckie Andrzeja Tomczaka; seminarium doktoranckie Zygmunta Kolankowskiego; seminarium doktoranckie Ireny Janosz-Biskupowej

Ke y word s: the Nicolas Copernicus University Archive Studies Department; The archive Studies doctoral program at the NCU; the NCU doctoral seminar; Andrzej Tomczak's doctoral seminar; Zygmunt Kolankowski's doctoral seminar; Irena Janosz-Biskup's doctoral seminar

Abstract

Andrzej Tomczak rozpoczął tworzenie seminarium doktoranckiego w 1965 r. i zaprosił do współudziału w nim Zygmunta Kolankowskiego, ówczesnego dyrektora Archiwum Polskiej Akademii Nauk. Nieco później do współprowadzenia seminarium została zaproszona Irena Janosz-Biskupowa. Uczestnikami seminarium byli zarówno absolwenci toruńskich studiów archiwistycznych, jak i czynni zawodowo pracownicy archiwów warszawskich. Spotkania odbywały się bardzo regularnie, a wystąpienia uczestników były okazją do żywej dyskusji nad problemami archiwistycznymi. W seminarium uczestniczyli m.in.: Olimpia Staroń, Weronika Klonowska, Aniela Przywuska, Bohdan Ryszewski, Zdzisław Chmielewski, Mieczysław Stelmach, Hali- 
na Robótka, Roman Marchwiński. Seminarium kierowane przez Andrzeja Tomczaka wygasło na początku lat 80. XX w. Wypromowano na nim 11 doktorów (A. Tomczak - 8; Z. Kolankowski - 2; I. Janosz-Biskupowa - 1). Pięciu doktorów Tomczaka uzyskało profesury, w tym trzy tytularne. Z kolei z seminariów jego uczniów wyszło wielu doktorów następnego pokolenia.

Historia seminarium doktoranckiego Zakładu Archiwistyki Uniwersytetu Mikołaja Kopernika jest odtwarzana głównie na podstawie wspomnień. Prowadzone systematycznie, ale zachowane we fragmentach protokoły wyraźnie ustępują w dokładności wspomnieniom.

Już dwukrotnie publikowałem fragmenty wspomnień z mojego toruńskiego okresu aktywnej pracy zawodowej i wspominałem o seminarium doktoranckim, zorganizowanym przez profesora Andrzeja Tomczaka w 1965 r. na Uniwersytecie Mikołaja Kopernika. W tytule artykułu jest pewna niedokładność: Zakład Archiwistyki został wyodrębniony w 1968 roku, zatem moje wspomnienie obejmuje także czas prahistoryczny, kiedy następowały fakty prowadzące do powstania Zakładu i rozwoju toruńskiego ośrodka kształcenia archiwistów. Zatem cezurą początkową moich dzisiejszych wspomnień będzie początek mojego zatrudnienia w Wydziale Humanistycznym UMK w marcu 1966 r., poprzedzona kilkoma faktami wcześniejszymi, ustalonymi na podstawie różnych źródeł pisanych.

Profesor Andrzej Tomczak habilitował się w 1964 r., a w 1965 r. otrzymał etat docenta, który wówczas oznaczał status samodzielnego nauczyciela akademickiego, i otworzył możliwość promowania doktorów. Warto dodać, że w początkowym okresie swojego powtórnego zatrudnienia na UMK (został zwolniony z pracy w 1951 roku z przyczyn politycznych) dr Andrzej Tomczak zajmował się głównie historią Polski w XVI wieku, historią kartografii oraz metodą opracowania kartografików, natomiast zajęcia prowadził z nauk pomocniczych historii. Kiedy podjął wieloletnią pracę nad rozprawą habilitacyjną, zajął się - jak mi sam mówił - pod wpływem wybitnych archiwistów Adama Stebelskiego i Mariana Friedberga kancelarią biskupów włocławskich w okresie księgi wpisów. Był to fakt ważny w historii toruńskiego ośrodka kształcenia archiwistów. Oznaczał bowiem podjęcie nowych w istocie badań, należących do tematyki, związanej z kształceniem archiwistów, przejście w większym niż dotąd stopniu do tematyki związanej z archiwami i ich zasobem. Takich badań wcześniej nie było w ośrodku toruńskim. Prowadzący za- 
jęcia wybitni archiwiści - Ryszard Mienicki, Franciszek Paprocki i Wojciech Hejnosz - mieli z okresu wcześniejszego pewien dorobek naukowy, dotyczący archiwów, starali się zorganizować na nowo swoje warsztaty naukowe i podjąć nową problematykę, ale rzadko podejmowali tematy z zakresu archiwistyki. Zakres habilitacji dr Andrzeja Tomczaka, ustalony przez Radę Wydziału Humanistycznego UMK, obejmował historię polityczną XVI wieku oraz archiwoznawstwo. Habilitacja oznaczała dla nowego samodzielnego pracownika naukowego uzyskanie warunków dla nowych poczynań, które zaraz podjął.

Do roku 1968 ówczesny docent, Andrzej Tomczak, nie miał jeszcze własnego zakładu, archiwistyka zresztą nie miała samodzielności w strukturze Instytutu Historii, należała do Katedry Archiwistyki i Nauk Pomocniczych Historii, którą kierował docent Kazimierz Jasiński, wybitny znawca nauk pomocniczych historii, zwłaszcza dyplomatyki, genealogii i chronologii. Wykładowcą archiwistyki był natomiast wyznaczony do tego przez Naczelną Dyrekcję Archiwów Państwowych na prośbę UMK mgr, później dr, Franciszek Paprocki, znakomity archiwista nie tylko o ogromnym doświadczeniu zawodowym, ale doskonale znający literaturę archiwalną. Docent Tomczak wykładał archiwoznawstwo niedawno wówczas wydzielone jako osobny przedmiot z przedmiotu „archiwistyka”, prowadził też od czasu habilitacji na wszystkich latach specjalizacji archiwalnej seminaria magisterskie $\mathrm{z}$ archiwistyki. Wcześniej te seminaria prowadzili na przemian prof. Wojciech Hejnosz i dr Franciszek Paprocki. Ćwiczenia z archiwistyki prowadziła dr Krystyna Zielińska-Melkowska, absolwentka archiwistyki toruńskiej, specjalizująca się w dyplomatyce, bez zawodowego doświadczenia archiwalnego. Wydaje się, że docent Andrzej Tomczak od czasu swojej habilitacji przejmował inicjatywę w toruńskim ośrodku kształcenia archiwistów, zwłaszcza że dotychczasowi jej kierownicy wycofywali się: prof. Wojciech Hejnosz do Wydziału Prawa, a dr Franciszek Paprocki do UAM w Poznaniu, gdzie zresztą zajmował się naukowo historią Poznańskiego w XIX wieku. Pilne okazało się zatrudnienie pomocniczego pracownika naukowego z większym doświadczeniem zawodowym w archiwach. W wyniku krótkich poszukiwań zostałem w marcu 1966 r. zatrudniony na tym stanowisku i przejąłem bardzo szerokie obowiązki asystenta i jedynego pomocnika faktycznego kierownika Studium Archiwalnego. Jednym z warunków mojego zatrudnienia na UMK było zajęcie się badaniami z dziedziny archiwalnej, przede wszystkim podjęcie doktoratu $\mathrm{z}$ tego zakresu. 
W 1965 roku docent Andrzej Tomczak podjął tworzenie seminarium doktoranckiego. Była to ważna i dość trudna decyzja. Seminaria doktoranckie prowadzone były tylko przez niektórych profesorów. Problemem było też pozyskanie odpowiednich doktorantów, zwykle byli to asystenci i absolwenci własnego seminarium magisterskiego. Szczegóły powołania seminarium nie są mi znane. Docent Andrzej Tomczak pozyskał jako współprowadzącego seminarium docenta Zygmunta Kolankowskiego, historyka prawa, ale o praktyce archiwalnej i pewnym dorobku z zakresu archiwistyki. Był on dyrektorem Archiwum Polskiej Akademii Nauk. Wprowadził do seminarium grupę doświadczonych archiwistów warszawskich, pragnących uzyskać stopnie doktorów i mających dorobek z zakresu archiwistyki. Docent Andrzej Tomczak natomiast skupił na seminarium zdolnych absolwentów specjalizacji archiwalnej, wywodzących się z innych seminariów magisterskich. Ze środowiska warszawskiego do seminarium zostały przyjęte: Olimpia Staroń - bardzo znana archiwistka z Archiwum Akt Nowych, Weronika Klonowska z Archiwum Prezydium Rady Ministrów, Róża Wojciechowska z Archiwum Państwowej Komisji Planowania Gospodarczego, Halina Zubalowa z Archiwum Polskiej Akademii Nauk w Warszawie. Z pokolenia niedawnych absolwentów specjalizacji archiwalnej do seminarium zostały przyjęte Jolanta Adamska - absolwentka Studium Archiwalnego z seminarium magisterskiego prof. Bronisława Włodarskiego, Aniela Przywuska i Krystyna Muszyńska - młode archiwistyki z seminarium magisterskiego prof. Wojciecha Hejnosza. Uzupełniała skład seminarium Wanda Klesińska - doświadczona archiwistka z Wojewódzkiego Archiwum Państwowego w Gdańsku, która bardzo kompetentnie pracowała nad kancelarią miasta Elbląga.

Pierwsze posiedzenie seminarium odbyło się 4 listopada 1965 roku. Z zachowanego protokołu posiedzenia wynika, że ustalono regularne terminy comiesięcznych posiedzeń oraz omówiono tematy rozpraw doktorskich. Z protokołu wynika także, że grupa archiwistów warszawskich miała już ustalone tematy i niektórzy dość zaawansowane dysertacje. Pracowano nad archiwami technicznymi w PRL (Olimpia Staroń), kancelarią Prezydium Rady Ministrów (Weronika Klonowska), kancelarią centralnych organów planowania gospodarczego PRL (Róża Wojciechowska), kancelarią miasta Elbląga (Wanda Klesińska), problemami mikrofilmowania (Halina Zubalowa). Jedno z pierwszych posiedzeń wypełnił referat Anieli Przywuskiej na temat archiwistyki jako nauki w świetle poglądów archiwistów polskich, który wywołał bardzo żywą dyskusję. Posiedzenia odbywały się bardzo regularnie 
i zawsze były okraszone dysputami. Poza docentami Andrzejem Tomczakiem i Zygmuntem Kolankowskim udział w nich brała zatrudniona od 1966 r. bardzo aktywna w dyskusjach dr Irena Janosz-Biskupowa i jako protokolantka dr Krystyna Zielińska. Natomiast wycofały się z seminarium po paru miesiącach bardzo zdolna i znana archiwistka z Koszalina Krystyna Muszyńska oraz Jolanta Adamska, a później dość nieregularnie współpracowała Aniela Przywuska, znakomita archiwistka z Gdańska, która obroniła w terminie późniejszym doktorat pod kierunkiem profesora Tomczaka.

Od kwietnia przybył jako uczestnik i sekretarz seminarium Bohdan Ryszewski, starszy asystent Zakładu Archiwistyki. Przejąłem od dr Krystyny Zielińskiej prowadzenie sekretariatu seminarium i wstępnie zająłem się z przyszłym promotorem, docentem Andrzejem Tomczakiem, wyborem tematu mojej rozprawy doktorskiej. Początkowo miała ona dotyczyć kancelarii urzędów gubernialnych w Królestwie Polskim w latach po 1867 r. Do podjęcia tego rodzaju tematu miałem odpowiednie przygotowanie w zakresie wiedzy historyczno-ustrojowej i aktoznawczej, natomiast nie miałem kompetencji metodologicznej. Praca wymagała żmudnej kwerendy w zasobie kilku archiwów. Zdaje się, że temat nie odpowiadał też mojemu temperamentowi badawczemu - jak wiadomo nigdy nie opracowałem w swoim życiu podobnego tematu, wymagającego bardzo żmudnej i długotrwałej kwerendy archiwalnej. Bieg wydarzeń w naszym małym środowisku zmienił jednak sytuację w sposób zasadniczy. Przerwał dalszą współpracę z UMK dr Franciszek Paprocki i w tej nowej sytuacji obaj kierownicy Katedry zdecydowali o powierzeniu wykładów z archiwistyki na IV roku dr Irenie Janosz-Biskupowej, a na roku III wówczas magistrowi, Bohdanowi Ryszewskiemu. Przewidziany dla mnie wykład obejmował zagadnienia wstępne z archiwistyki z elementami teorii oraz metodykę archiwalną okresu akt spraw. Nieoczekiwane zaufanie, jakim obdarzyli mnie na początku pracy uniwersyteckiej obaj kierownicy Katedry - profesorowie Kazimierz Jasiński i Andrzej Tomczak - w sposób decydujący wpłynęło na przebieg mojej kariery zawodowej. Od czerwca do końca września intensywnie przygotowywałem się do wykładów na podstawie pracowicie gromadzonej literatury. Otrzymałem od profesora Tomczaka bardzo dobry program wykładów z archiwistyki, wyraźnie nawiązujący (wiem to teraz) do programów kształcenia archiwistów okresu międzywojennego. Problematyka wykładów teoretycznych niezmiernie mnie zajęła. Narodził się pomysł naukowego opracowania tych podstawowych zagadnień archiwistyki. W czasie pierwszego powakacyjnego spotkania z profesorem Andrzejem 
Tomczakiem w Warszawie, na wyjazdowym seminarium doktoranckim, opowiedziałem o pomyśle pracy doktorskiej na temat naukowości archiwistyki, jej przedmiotu, zakresu i podziału. Profesor ten pomysł zaakceptował i polecił przygotować koncepcję pracy na następne seminarium doktoranckie. Tekst przygotowanego konspektu zachował się w moim archiwum osobistym. Od tej pory na każde pierwsze, wrześniowe posiedzenie seminarium przygotowywałem tekst kolejnego rozdziału pracy doktorskiej, stosując się dokładnie do wymagań docenta Tomczaka: tekst był napisany w całości, z przypisami, był przepisany na tzw. przebitce $\mathrm{w}$ sześciu egzemplarzach i rozesłany w taki sposób, aby wszyscy uczestnicy seminarium mogli go przeczytać. Obowiązkiem moim, jako asystenta, było zrealizować te wymagania wzorowo. Cały kolejny rok poświęcałem na zbieranie materiału do kolejnych rozdziałów. Całe wakacje przeznaczone były na analizę zagadnień i pisanie tekstu. Rozprawa po opublikowaniu liczy wprawdzie cztery rozdziały, ale w pierwotnej koncepcji miała mieć trzy rozdziały i przy przyjętej metodzie pracy powstała po trzech latach. Latem 1969 roku rozprawa pt. Archiwistyka - przedmiot, zakres, podziat. Studia nad problemem została ukończona. Szybkie tempo przygotowania mojej rozprawy wynikało przede wszystkim z jej teoretycznego charakteru. Ten typ badań odpowiadał moim zdolnościom. Korzystałem też z możliwości częstych konsultacji z promotorem, który był bardzo zainteresowany tematem. Z inicjatywy profesora odbyło się w Katedrze spotkanie naukowe poświęcone mojej rozprawie z udziałem docentów: Kazimierza Jasińskiego, Andrzeja Tomczaka, Zygmunta Kolankowskiego, dr Ireny Janosz Biskupowej, dr Krystyny Zielińskiej (Melkowskiej) oraz osób zaproszonych: profesora Wojciecha Hejnosza, docenta Ireneusza Ihnatowicza z Uniwersytetu Warszawskiego, dra Tadeusza Grygiera z archiwum w Olsztynie i dra Czesława Biernata z archiwum w Gdańsku. Mój referat został przyjęty sceptycznie przez większość zebranych, pewne poparcie uzyskał tylko ze strony docentów: Andrzeja Tomczaka, Zygmunta Kolankowskiego i Ireneusza Ihnatowicza. Forma podobnych spotkań naukowych, uzupełniających spotkania seminaryjne, zasługuje na uwagę i naśladowanie. Rozprawa po ukończeniu i poprawkach, wynikających z uwag promotora, zyskała Jego pozytywną ocenę. Miarą tego niech będzie zgłoszenie rozprawy do publikacji w „Rocznikach Towarzystwa Naukowego w Toruniu” jeszcze przed obroną doktoratu (choć już po recenzjach, o ile dobrze pamiętam). Dnia 6 marca 1970 roku przed Radą Wydziału Humanistycznego w pełnym składzie odbyła się pierwsza obrona doktorska naszego seminarium z udziałem, poza doktorantem i promotorem, 
w roli recenzentów docentów Ireneusza Ihnatowicza i Zygmunta Kolankowskiego. Do następnej obrony upłynąć musiało sporo lat, przede wszystkim z powodu dość wolnego tempa pracy zaawansowanych przecież w pisaniu rozpraw uczestniczek z Warszawy.

W latach następnych skład seminarium zmieniał się, przybywali zainteresowani archiwistyką i pracujący w archiwach wychowankowie seminarium magisterskiego Andrzeja Tomczaka. W 1967 r. uczestnikiem seminarium przez rok był Roman Marchwiński, który po roku odszedł z UMK, ale pozostawał w kontakcie z profesorem i w 1990 roku pod Jego kierunkiem obronił pracę doktorską pt. Obraz geograficzno-historyczny Polski w "Polonii” Marcina Kromera. Następnie przybyli na seminarium obecny profesor Uniwersytetu Szczecińskiego Zdzisław Chmielewski oraz zmarły przedwcześnie, bardzo zdolny profesor tegoż Uniwersytetu, Mieczysław Stelmach, którzy kolejno przygotowali i obronili na seminarium profesora Tomczaka rozprawy doktorskie. Zdzisław Chmielewski uzyskał tytuł doktora w 1976 na podstawie rozprawy pt. Kancelaria miejska Ziem Odzyskanych w latach 1945-1950, a Mieczysław Stelmach w 1980 r. obronił doktorat na podstawie rozprawy pt. Kancelaria pruskich urzędów administracji państwowej na przyktadzie rejencji $w$ latach 1808-1945. Od 1970 r. przygotowywał pod kierunkiem prof. Tomczaka pracę doktorską Zbigniew Górski, zatrudniony w Zakładzie Archiwistyki jako asystent. Obronił on rozprawę doktorską o księgach Starego Miasta Warszawy (studium dyplomatyczne) w 1978 r. W 1971 r. uzupełniła skład seminarium obecna profesor UMK, Halina Robótka, także wychowanka seminarium magisterskiego profesora, która obroniła rozprawę doktorską na temat Mapa jako obiekt archiwalny w 1980 r. Powróciła na seminarium w tych czasach Aniela Przywuska, archiwistka Archiwum Państwowego w Gdańsku, która w 1978 r. obroniła pracę doktorska pt. Kancelaria gdańskich wtadz wojewódzkich w latach 1945-1958. Uczestniczyła też w seminarium Henryka Duczkowska-Moraczewska (z seminarium magisterskiego prof. Witolda Łukaszewicza), która przygotowała pod kierunkiem doc. Ireny Janosz-Biskupowej rozprawę pt. Kancelaria i archiwa uniwersyteckie w Polsce Ludowej, obronioną w 1978 r.

W 1974 roku rozluźnił się mój udział w pracach seminarium doktoranckiego profesora Tomczaka w związku z objęciem bardzo absorbującego stanowiska dyrektora Biblioteki Uniwersyteckiej UMK. Prowadziłem jednak większość zajęć z archiwistyki, seminaria magisterskie i czasami bywałem na posiedzeniach seminarium doktoranckiego. Moje miejsce w pracach organi- 
zacyjnych seminarium przejął nowy asystent, Maciej Gołembiowski, wychowanek seminarium magisterskiego profesora Karola Górskiego. Przygotował rozprawę doktorską na sugerowany przeze mnie temat System informacji archiwalnej, obronioną w 1981 r., której promotorką była docent Krystyna Wyczańska z PAN. Był bardzo aktywnym i cennym pracownikiem Zakładu Archiwistyki, na nim bowiem aż do mojego powrotu w 1986 r. spoczywały sprawy organizacyjne oraz programowe specjalizacji. Nie zrobił jednak w przewidzianym terminie habilitacji i po przejściu na etat techniczny owocnie współpracował ze mną do końca mojego zatrudnienia na stanowisku kierownika Zakładu Archiwistyki. W 1981 r. skład Zakładu uzupełnił Witold Szczuczko, uczeń profesora Karola Górskiego, pod którego kierunkiem w 1985 r. obronił doktorat i choć podjął ciekawy temat rozprawy habilitacyjnej, nie zdołał jej w terminie ukończyć. W tym też okresie pojawił się na seminarium ks. Jan Wiśniewski, który obronił doktorat pt. Kancelaria biskupia Marcina Kromera (1569-1589) w 1982 r. Chyba ostatnią doktorantką omawianego seminarium była Lidia Wakuluk, z seminarium magisterskiego prof. Karola Górskiego, która jednak po zamknięciu regularnych posiedzeń seminaryjnych profesora Tomczaka, po pewnej przerwie, stała się uczestniczką mojego seminarium i obroniła doktorat w 1992 r. Seminarium prof. Andrzeja Tomczaka właściwie wygasło. Kiedy okazało się, że nie ma gotowych prac lub rozdziałów do referowania, profesor Tomczak zdecydował, że spotkanie kolejne seminarium odbędzie po zgłoszeniu się referenta. O ile pamiętam, miało to miejsce w 1982 roku lub trochę później.

Rezultaty działającego około osiemnastu lat seminarium były ważne jako doświadczenie dla kształcenia doktorów w zakresie problematyki archiwalnej. Sam zakładając i prowadząc przez przeszło dwadzieścia pięć lat własne seminarium doktoranckie, korzystałem z tych doświadczeń.

W wyniku pracy seminarium wypromowano: profesor Andrzej Tomczak ośmiu doktorów, prof. Zygmunt Kolankowski dwa doktoraty, doc. Irena Janosz-Biskupowa (habilitowana w 1971 r.) jeden doktorat. Spośród ośmiu doktorów profesora Andrzeja Tomczaka pięciu uzyskało profesury, w tym trzy tytularne. Z kolei z ich seminariów (Bohdan Ryszewskiego, Zdzisława Chmielewskiego, Haliny Robótki, Mieczysława Stelmacha, Jana Wiśniewskiego) wyszło wielu doktorów następnego, choć nie ostatniego przecież, pokolenia. Zatem działalność omawianego seminarium wiele wniosła do rozwoju archiwistyki polskiej. 


\section{Su m m a ry}

The reminiscence of the doctoral seminar of the Nicolaus Copernicus University Archive Studies Department from 1966 to 1974

Andrzej Tomczak began creating a doctoral seminar in 1965 and he invited Zygmunt Kolankowski, who had been the director of the Archive of the Polish Academy of Sciences (PAN). A little later, Irena Jarosz - Biskup was also invited to contribute to it. Both the alumni of the Torun Archive Studies Department, and the active employees of the Warsaw archives, took part in these seminars. The meetings had been held regularly, and the participants' presentations had served as an opportunity for an animated debate on the subject of the archive-related problems. The seminar's participants were inter alia: Olimpia Staron, Weronika Klonowska, Aniela Przywuska, Bohdan Ryszewski, Zdzislaw Chmielewski, Mieczyslaw Stelmach, Halina Robotka, Roman Marchwinski. The seminar led by Andrzej Tomczak was terminated at the beginning of the 1980s. Eleven degrees had been obtained in the course of the aforementioned seminar. (A. Tomczak conferred 8 PhD degrees; Z. Kolankowski - 2; I. Janosz-Biskupowa - 1) Five of the Tomczak's doctoral degree recipients, later obtained professorships, three from among those received the titles from the President of Poland. His students' seminars have, in turn, assisted in producing the next generation's doctors. 